\title{
Analisis Portofolio Optimum Saham Syariah Menggunakan Liquidity Adjusted Capital Asset Pricing Model (LCAPM)
}

\author{
Nila Cahyati \\ Program Studi Matematika Fakultas Sains dan Teknologi, UIN Sunan Kalijaga, Jl. Marsda Adisucipto \\ No. 1 Yogyakarta, Indonesia
}

Korespondensi; Email: nilacahyati53@yahoo.com

\begin{abstract}
Abstrak
Investasi mempunyai karakteristik antara return dan resiko. Pembentukan portofolio optimal digunakan untuk memaksimalkan keuntungan dan meminimumkan resiko. Liquidity Adjusted Capital Asset Pricing Model (LCAPM) merupakan metode pengembangan baru dari CAPM yang dipengaruhi likuiditas. Indikator likuiditas apabila digabungkan dengan metode CAPM dapat membantu memaksimalkan return dan meminimumkan resiko. Tujuan penelitian adalah membandingkan expected retun dan resiko saham serta mengetahui proporsi pada portofolio optimal. Sampel yang digunakan merupakan saham JII (Jakarta Islamic Index) periode Januari 2013 - November 2014. Hasil penelitian menunjukkan bahwa expected return portofolio LCAPM sebesar 0,0956 dengan resiko 0,0043 yang membentuk proporsi saham AALI $(55,19 \%)$ dan saham PGAS $(44,81 \%)$.
\end{abstract}

Kata Kunci: CAPM; LCAPM; Portofolio O ptimal; Saham Syariah

\begin{abstract}
Characteristics of Investments is return and risk. Formation of optimal portfolio is used to maximize profits and minimize risks. Liquidity Adjusted Capital Asset Pricing Model (LCAPM) is a new development of the CAPM method which affected liquidity. Liquidity indicators when combined with the CAPM method can help to maximize return and minimize risk. The research objective was to compare the expected retun and share the risk and determine the proportion of the optimal portfolio. The samples used are shares JII (Jakarta Islamic Index) in the period January 2013 - December 2014. The results showed that the expected return of the portfolio amounted LCAPM 0.0043 0.0956 with the risk that form AALI proportion $(55.19 \%)$ and shares PGAS $(44.81 \%)$.
\end{abstract}

Keywords: CAPM; LCAPM; Portofolio Optimal; Islamic stocks

\section{Pendahuluan}

Investasi merupakan komitmen menempatkan harta atau dana dengan harapan memperoleh keuntungan di masa yang akan datang (Tandelilin, 2007: 2). Bodie, Cane dan Marcus mengatakan bahwa terdapat dua langkah yang harus dilakukan dalam proses investasi, yaitu pertama, melakukan analisis terhadap return dan resiko saham-saham yang akan dimasukkan ke dalam portofolio. Kedua adalah membentuk portofolio optimal dari saham-saham yang dipilih (Zubir, 2013: 2).

Model yang popular digunakan dalam pembentukan portofolio optimal adalah model Capital Asset Pricing Model (CAPM). Capital Asset Pricing Model (CAPM) dikembangkan pertama kali oleh William Sharpe, John Lintner, dan Jan Mossin (Jogiyanto, 2000: 311). CAPM merupakan model analisis portofolio yang menghubungkan antara aset-aset beresiko dengan aset bebas resiko. Model ini berperan penting dalam bidang keuangan yang digunakan untuk memprediksi hubungan antara expected return dan resiko suatu aset (Zubir, 2013: 197).

Perkembangan CAPM yang semakin modern terdapat penemu yang mengembangkan suatu likuiditas pada model CAPM. Model tersebut dinamakan Liquidity Adjusted Capital Asset pricing model (LCAPM) 
yang dikembangkan pertama kali oleh Acharya dan Pedersen pada tahun 2005. LCAPM merupakan model CAPM yang dipengaruhi oleh resiko likuiditas. Resiko likuiditas (liquidity risk) adalah resiko yang berkaitan dengan kesulitan untuk mencairkan portofolio atau menjual saham karena tidak ada yang membeli saham tersebut (Zubir, 2013: 22). Ukuran likuiditas saham dapat dianalisis dengan menggunakan bid-ask spread, volume transaksi perdagangan saham dan frekuensi perdagangan. Bidask spread menunjukkan perbedaan antara nilai permintaan tertinggi investor yang ingin menjual dan penawaran terendah dealer yang ingin membeli. (Jogiyanto, 2010: 163).

Investor dapat mengambil keputusan investasi yang dipengaruhi oleh beberapa indikator salah satunya adalah likuiditas saham. Likuiditas saham merupakan ukuran jumlah transaksi suatu saham di pasar modal dalam suatu periode tertentu. Jika semakin likuid saham maka frekuensi transaksi saham semakin tinggi (Mulyana, 2011: 2). Selain itu, likuiditas saham dapat diukur dari volume perdagangan suatu saham. Semakin tinggi volume transaksi maka semakin cepat dan mudah sebuah saham diperjualbelikan sehingga perubahan saham menjadi semakin cepat. Pengukuran likuiditas saham dilakukan dengan melihat Trading Volume Activity (TVA). Trading Volume Activity (TVA) merupakan suatu instrumen yang dapat digunakan untuk melihat reaksi pasar terhadap suatu informasi melalui parameter pergerakan aktivitas volume perdagangan di pasar modal (Mulyana, 2011: 2).

Untuk itu, tulisan ini akan membahas analisis portofolio optimum saham syariah menggunakan model Liquidity Adjusted Capital Asset Pricing Model (LCAPM) periode Januari 2013 November 2014.

\section{Landasan Teori}

\section{Pasar Modal Syariah}

Pasar modal adalah tempat bertemunya pihak yang memiliki kelebihan dana dengan pihak yang membutuhkan dana dengan cara memperjualbelikan sekuritas. Berdasarkan UU No. 8 Tahun 1995, pasar modal merupakan suatu kegiatan yang bersangkutan dengan penawaran umum dan perdagangan efek, perusahaan publik yang berkaitan dengan efek yang diterbitkannya, serta lembaga dan profesi yang berkaitan dengan efek (Susanto, 2008: 10).

Berdasarkan Peraturan Nomor IX.A.13 tentang Penerbitan Efek Syariah, Pasar Modal Syariah (Efek Syariah) adalah pasar modal sebagaimana dimaksud dalam undang-undang pasar modal dan peraturan pelaksanaannya sesuai dengan akad maupun cara penerbitannya memenuhi prinsip-prinsip syariah di pasar modal (Suhartono \& Fadillah, 2009: 203).

Peraturan Bapepam-LK tentang Penerbitan Efek Syariah, angka 1 huruf b dan Fatwa Dewan Syariah Nasional No.40/DSN-MUI/X/2003 tentang pasar modal dan pedoman umum penerapan prinsip syariah di bidang pasar modal, Pasal 5 ayat 1 dan 2 (Pompe, 2010: 846).

a. Pelaksanaan transaksi harus dilakukan menurut prinsip kehatihatian serta tidak diperbolehkan melakukan spekulasi dan manipulasi yang didalamnya mengandung unsur dharar, gharar, riba, maisir, risywah, maksiat dan kezhaliman.

b. Transaksi yang mengandung unsur dharar, gharar, riba, maisir, risywah, maksiat dan kezhaliman sebagaimana dimaksud ayat 1 diatas meliputi:

1) Najsy yaitu melakukan penawaran palsu.

2) Bai al-madum yaitu melakukan penjualan atas barang (efek syariah) yang belum dimiliki (short selling).

3) Insider trading yaitu memakai informasi orang dalam untuk memperoleh keuntungan atas transaksi yang dilarang.

4) Menimbulkan transaksi yang menyesatkan.

5) Ihtikar (penimbunan) yaitu melakukan pembelian atau dan pengumpulan suatu efek syariah untuk menyebabkan perubahan efek syariah dengan tujuan mempengaruhi pihak lain.

6) Margin trading yaitu melakukan transaksi atas efek syariah dengan fasilitas pinjaman berbasis bunga atas kewajiban penyelesaian pembelian efek syariah tersebut.

\section{Jakarta Islamic Index (JII)}

Bursa Efek Indonesia (BEI) terdapat beberapa jenis indeks. Namun, diantara indeks tersebut yang beroperasi berdasarkan prinsip syariah hanya jakarta islamic index (JII). JII dibentuk dari hasil kerjasama 
antara PT. BEI dengan PT. Danareksa Invesment Management (PT. DIM) yang beroperasi sejak tanggal 3 Juli 2000 yang setiap periode sahamnya yang masuk Jakarta Islamic Index (JII) berjumlah 30 saham yang memenuhi kriteria syariah pada tahun 1 Januari 1995 sebagai base date (dengan nilai 100). Niat peluncuran Jakarta Islamic Index (JII) adalah untuk meningkatkan kepercayaan investor agar melakukan investasi pada saham berbasis syariah, memberikan manfaat keuntungan bagi pemodal yang berinvestasi di bursa efek dan menjadi tolak ukur kinerja (bencmark) dalam memilih portofolio saham yang halal dan sebagai sarana mendongkrak nilai kapitalisasi saham di Bursa Efek Jakarta (BEJ). Hal ini didasarkan pada potensi dana umat Islam di Indonesia yang luar biasa besarnya (Mahmud \& Rukmana, 2010: 148).

Jakarta Islamic Index (JII) merupakan satusatunya indeks saham di Indonesia yang menghitung indeks harga ratarata saham untuk jenis kegiatan usaha yang memenuhi kriteria syariah. Hal ini didasarkan pada sahamsaham yang masuk dalam indeks syariah adalah emiten yang kegiatan usahanya tidak bertentangan dengan prinsip syariah. Syarat pemilihan saham pada umumnya sama dengan saham LQ45. Namun, pada saham Jakarta Islamic Index (III) lebih ditekankan pada jenis usaha yang tidak boleh bertentangan dengan syariah islam.

\section{Likuiditas $\boldsymbol{C}_{\boldsymbol{i}}$}

Likuiditas menurut Bursa Efek Indonesia adalah kelancaran yang menunjukkan tingkat kemudahan dalam mencairkan modal investasi. Pengukuran likuiditas saham dilakukan dengan melihat Trading Volume Activity (TVA). Trading Volume Activity (TVA) merupakan suatu instrumen yang dapat digunakan untuk melihat reaksi pasar terhadap suatu informasi melalui parameter pergerakan aktivitas volume perdagangan di pasar modal (Mulyana, 2011: 4).

$$
\text { Likuiditas }\left(C_{i}\right)=T=\frac{J \imath \quad h V_{\imath} \quad T}{T \quad V l u \quad S h a}
$$

\section{Ekpektasi likuiditas saham $\boldsymbol{E}\left(\boldsymbol{C}_{\boldsymbol{i}}\right)$}

Return ekspektasi likuiditas diperoleh dari rata-rata return likuiditas dengan rumus sebagai berikut:

$$
\begin{aligned}
E\left(C_{i}\right) & =R-r_{1} \quad\left(C_{i}\right) \\
& =\frac{\sum_{i=1}^{n} C_{i}}{n}
\end{aligned}
$$

dengan:

$E\left(C_{i}\right)=$ ekspektasi likuiditas pada saham ke-i

$R_{C_{i}}=$ return likuiditas saham ke-i

$n \quad=$ banyak data

\section{Likuiditas Pasar $\boldsymbol{C}_{\boldsymbol{m}}$}

Likuiditas pasar adalah nilai likuiditas yang diperoleh berdasarkan volume transaksi pasar pada suatu lembar saham yang terdapat pada IHSG (total volume pasar).

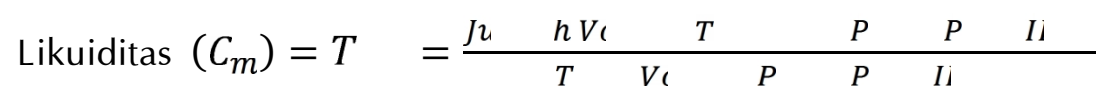

\section{Beta Likuiditas}

Beta likuiditas merupakan pengukur resiko dari suatu sekuritas atau portofolio likuiditas saham terhadap resiko likuiditas pasar. Beta likuiditas memiliki empat beta antara lain sebagai berikut (Archarya \& Pedersen, 2005: 381):

$$
\begin{aligned}
& \beta_{1 i}=\frac{C\left(R_{i}, R_{m}\right)}{V r\left(R_{m}-C_{m}\right)} \\
& \beta_{2 i}=\frac{C \quad\left(C_{i}, C_{m}\right)}{V \quad\left(R_{m}-C_{m}\right)}
\end{aligned}
$$




$$
\begin{aligned}
& \beta_{3 i}=\frac{C \quad\left(R_{i}, R_{m}\right)}{V \quad\left(R_{m}-C_{m}\right)} \\
& \beta_{4 i}=\frac{C \quad\left(C_{i}, R_{m}\right)}{V \quad\left(R_{m}-C_{m}\right)}
\end{aligned}
$$

Berdasarkan keempat beta likuiditas tersebut yang menandakan empat resiko likuiditas. $\beta_{1 i}$ merupakan beta likuiditas yang mengukur hubungan antara return sekuritas ke-i terhadap return pasar. $\beta_{2 i}$ merupakan beta likuiditas yang mengukur hubungan antara likuiditas sekuritas ke-i terhadap likuiditas pasar. $\beta_{3 i}$ merupakan beta likuiditas yang mengukur hubungan antara return sekuritas terhadap likuiditas pasar. $\beta_{4 i}$ merupakan beta likuiditas yang mengukur hubungan antara likuiditas sekuritas ke-i terhadap return pasar.

\section{Lamda Likuiditas $\left(\boldsymbol{\lambda}_{\boldsymbol{c}}\right)$}

Lamda likuiditas merupakan suatu lamda yang digunakan dalam likuiditas saham pada LCAPM. Lamda likuiditas dapat ditulis dengan rumus sebagai berikut (Archarya \& Pedersen, 2005: 381):

dengan:

$$
\lambda_{c}=E\left(R_{m}-C_{m}-R_{f}\right)
$$

$R_{m}=$ return pasar

$C_{m}=$ likuiditas pasar

$R_{f} \quad=$ return bebas resiko

\section{Portofolio}

Portofolio merupakan sekumpulan dari berbagai macam sekuritas suatu saham.

\section{Return Portofolio}

Return terdiri dari dua bentuk, yaitu realized return (return realisasi) dan expected return (return ekspektasi) (Suhartono \& Fadillah, 2009: 81). Return realisasi portofolio adalah rata-rata dari realized return (return realisasi) setiap sekuritas tunggal pada suatu portofolio, sedangkan return ekspektasi adalah rata-rata dari expected return (return ekspektasi) setiap sekuritas tunggal pada suatu portofolio.

Return realisasi portofolio dapat ditulis dengan rumus sebagai berikut:

$$
\begin{aligned}
R_{p} & =w_{1} R_{1}+w_{2} R_{2}+\cdots+w_{n} R_{n} \\
& =\sum_{i=1}^{n} w_{i} R_{i}
\end{aligned}
$$

Secara umum, bentuk matriks dari return portofolio dapat ditulis sebagai berikut:

$$
\begin{aligned}
R_{p} & =w_{1} R_{1}+w_{2} R_{2}+\cdots+w_{n} R_{n} \\
& =\left[\begin{array}{llll}
w_{1} & w_{2} & \cdots & w_{n}
\end{array}\right]\left[\begin{array}{c}
R_{1} \\
R_{2} \\
\vdots \\
R_{n}
\end{array}\right] \\
& =w^{T} R
\end{aligned}
$$

Return ekspektasi portofolio dapat ditulis dengan rumus sebagai berikut:

$$
\begin{aligned}
E\left(R_{p}\right) & =w_{1} E\left(R_{1}\right)+w_{2} E\left(R_{2}\right)+\cdots+w_{n} E\left(R_{n}\right) \\
& =\sum_{i=1}^{n} w_{i} E\left(R_{i}\right)
\end{aligned}
$$


dengan:

$w_{1} \quad=$ proporsi saham ke-i dalam portofolio

$E\left(R_{i}\right)=$ expected return saham ke-i dalam portofolio

\section{Resiko Portofolio}

Resiko portofolio merupakan resiko yang terbentuk dalam portofolio berdasarkan nilai varian sekuritas dalam portofolio tersebut.

Resiko portofolio dapat ditulis dalam rumus sebagai berikut:

$$
\begin{aligned}
V \quad\left(R_{p}\right) & =V \quad\left(w R_{i}\right) \\
& =w V \quad\left(R_{i}\right) \\
& =w \sum \mathrm{w}
\end{aligned}
$$

Nilai $V \quad\left(R_{p}\right)=V \quad\left(w R_{i}\right)$ diperoleh berdasarkan nilai kombinasi linear matriks mean dan kovarian. Matriks varian-kovarian $(\Sigma)$ pada resiko portofolio merupakan diagonal utama matriks dari matriks varian-kovarian tersebut.

\section{Liquidity Adjusted Capital Asset Pricing Model (LCAPM)}

LCAPM (Liquidity Adjusted Capital Asset Pricing Model) merupakan suatu model pengembangan dari model CAPM yang mempunyai pengaruh resiko likuiditas. LCAPM pertama kali dikembangkan oleh Acharya dan Pedersen pada tahun 2005.

Asumsi LCAPM sama dengan CAPM yaitu memiliki pasar modal dalam kondisi ekuilibrium. Perbedaannya adalah model LCAPM dipengaruhi oleh resiko likuiditas. Resiko likuiditas adalah resiko yang berkaitan dengan kesulitan untuk mencairkan portofolio atau menjual saham karena tidak ada yang membeli saham tersebut (Zubir, 2013: 22). Likuiditas dapat dihitung dengan menggunakan Trading Volume Activity $(T V A)$. Selain itu, metode LCAPM dipengaruhi oleh empat beta antara lain $\beta_{1 i}$ digunakan untuk mengukur return sekuritas terhadap return pasar, $\beta_{2 i}$ digunakan untuk mengukur likuiditas sekuritas terhadap likuiditas pasar, $\beta_{3 i}$ digunakan untuk mengukur return sekuritas terhadap likuiditas pasar dan $\beta_{4 i}$ digunakan untuk mengukur likuiditas sekuritas terhadap return pasar.

1. Penjabaran Rumus Dasar LCAPM

Pembentukan portofolio LCAPM (Liquidity Adjusted Capital Asset Pricing Model) berdasarkan persamaan sebagai berikut

$$
\bar{R}_{\iota}=R_{f}+E\left(C_{i}\right)+\lambda \beta_{1 i}+\lambda \beta_{2 i}-\lambda \beta_{3 i}-\lambda \beta_{4 i}
$$

2. Slope $\theta$ pada LCAPM

Slope $\theta$ pada LCAPM merupakan hubungan antara kombinasi sekuritas beresiko dan sekuritas bebas resiko dengan return portofolio yang dipengaruhi oleh likuiditas portofolio $\left(C_{p}\right)$, sehingga dapat dibentuk slope $\theta$ pada LCAPM dengan rumus sebagai berikut:

$$
\theta=\frac{E\left(R_{p}-C_{p}\right)-R_{f}}{\sigma_{p}}
$$

Fungsi Objektif adalah memaksimumkan slope $\theta$ garis yang menyinggung efficient frontier dengan return portofolio dipengaruhi oleh likuiditas portofolio $\left(C_{p}\right)$ diselesaikan dengan metode Lagrange dengan kendala $\sum_{i=1}^{n} w_{i}=1$.

$$
E\left(R_{p}-C_{p}\right)-R_{f}=\sum_{i=1}^{n} w_{i} E\left(R_{i}-C_{i}\right)-\sum_{i=1}^{n} w_{i} \cdot R_{f}
$$




$$
\begin{aligned}
& E\left(R_{p}-C_{p}\right)-R_{f}=\sum_{i=1}^{n} w_{i}\left[E\left(R_{i}-C_{i}\right)-R_{f}\right] \\
& E\left(R_{p}-C_{p}\right)-R_{f}=w_{i} \sum_{i=1}^{n}\left[E\left(R_{i}-C_{i}\right)-R_{f}\right]
\end{aligned}
$$

Varian portofolio dapat dibentuk sebagai berikut:

$$
\sigma_{p}=\left(\sum_{i=1}^{n} w_{i}^{2} \sigma_{l i}^{2}+\sum_{i=1}^{n} \sum_{j=1}^{n} w_{i} w_{j} \sigma_{l l}\right)^{\frac{1}{2}}
$$

Substitusi persamaan (11) dan persamaan (12) ke slope $\theta$ pada persamaan (10) sehingga menjadi

$$
\begin{aligned}
\theta & =\frac{w_{i} \sum_{i=1}^{n}\left[E\left(R_{i}-C_{i}\right)-R_{f}\right]}{\left(\sum_{i=1}^{n} w_{i}{ }^{2} \sigma_{l}{ }^{2}+\sum_{i=1}^{n} \sum_{j=1}^{n} w_{i} w_{j} \sigma_{l_{i}}\right)^{\frac{1}{2}}} \\
\theta & =w_{i} \sum_{i=1}^{n}\left[E\left(R_{i}-C_{i}\right)-R_{f}\right] \cdot\left(\sum_{i=1}^{n} w_{i}{ }^{2}{\sigma_{l i}}^{2}+\sum_{i=1}^{n} \sum_{j=1}^{n} w_{i} w_{j} \sigma_{l i}\right)^{-\frac{1}{2}}
\end{aligned}
$$

Berdasarkan persamaan (12) dapat dibentuk

$$
\begin{aligned}
& \theta_{1}=w_{i} \sum_{i=1}^{n}\left[E\left(R_{i}-C_{i}\right)-R_{f}\right] \\
& \theta_{2}=\left(\sum_{i=1}^{n} w_{i}^{2} \sigma_{l i}^{2}+\sum_{i=1}^{n} \sum_{j=1}^{n} w_{i} w_{j} \sigma_{l i}\right)^{-\frac{1}{2}}
\end{aligned}
$$

Maksimumkan nilai $\theta$ dengan cara turunan pertama $\theta$ terhadap $w_{i}$ sama dengan nol.

$\theta_{1}=\left[E\left(R_{i}-C_{i}\right)-R_{f}\right]$

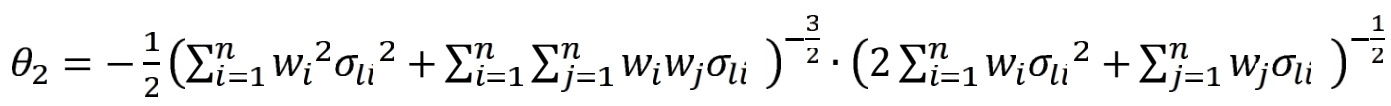

$\theta=\theta_{1} \theta_{2}+\theta_{2} \theta_{1}$

$$
\begin{aligned}
\theta= & w_{i} \sum_{i=1}^{n}\left[E\left(R_{i}-C_{i}\right)-R_{f}\right] \cdot-\frac{1}{2}\left(\sum_{i=1}^{n} w_{i}{ }^{2} \sigma_{l i}{ }^{2}+\sum_{i=1}^{n} \sum_{j=1}^{n} w_{i} w_{j} \sigma_{l i}\right)^{-\frac{3}{2}} \cdot \\
& \left(2 \sum_{i=1}^{n} w_{i}{\sigma_{l i}}^{2}+\sum_{j=1}^{n} w_{j} \sigma_{l i}\right)+\left(\sum_{i=1}^{n} w_{i}{ }^{2}{\sigma_{l i}}^{2}+\sum_{i=1}^{n} \sum_{j=1}^{n} w_{i} w_{j} \sigma_{l i}\right)^{-\frac{1}{2}} \cdot\left[E\left(R_{i}-C_{i}\right)-R_{f}\right]
\end{aligned}
$$

Kemudian, mengalikan nilai $\theta$ dengan $\sigma_{p}$ dan menyamakan dengan nol sehingga menjadi

$$
\begin{aligned}
\theta= & w_{i} \sum_{i=1}^{n}\left[E\left(R_{i}-C_{i}\right)-R_{f}\right] \cdot-\left(\sum_{i=1}^{n} w_{i}{ }^{2}{\sigma_{l i}}^{2}+\sum_{i=1}^{n} \sum_{j=1}^{n} w_{i} w_{j} \sigma_{l i}\right)^{-1} \cdot \\
& \left(\sum_{i=1}^{n} w_{i} \sigma_{l i}{ }^{2}+\sum_{j=1}^{n} w_{j} \sigma_{l i}\right)+\left(\sum_{i=1}^{n} w_{i}{ }^{2}{\sigma_{l i}}^{2}+\sum_{i=1}^{n} \sum_{j=1}^{n} w_{i} w_{j} \sigma_{l i}\right)^{0} \cdot\left[E\left(R_{i}-C_{i}\right)-R_{f}\right] \\
= & -\frac{\sum_{i=1}^{n}\left[E\left(R_{i}-C_{i}\right)-R_{f}\right]}{\left(\sum_{i=1}^{n} w_{i}{ }^{2} \sigma_{l i}{ }^{2}+\sum_{i=1}^{n} \sum_{j=1}^{n} w_{i} w_{j} \sigma_{l i j}\right)} \cdot\left(\sum_{i=1}^{n} w_{i}{\sigma_{l i}}^{2}+\sum_{j=1}^{n} w_{j} \sigma_{l i}\right)+\left[E\left(R_{i}-C_{i}\right)-R_{f}\right]=0
\end{aligned}
$$

Misalkan $\varphi=\frac{\sum_{i=1}^{n}\left[E\left(R_{i}-C_{i}\right)-R_{f}\right]}{\left(\sum_{i=1}^{n} w_{i}{ }^{2} \sigma_{l}{ }^{2}+\sum_{i=1}^{n} \sum_{j=1}^{n} w_{i} w_{j} \sigma_{l i}\right)}$ sehingga persamaan (17), $\theta$ dapat diubah menjadi

$$
\theta=-\varphi \cdot\left(\sum_{i=1}^{n} w_{i}^{2} \sigma_{l i}^{2}+\sum_{i=1}^{n} w_{j} \sigma_{l i}\right)+\left[E\left(R_{i}-C_{i}\right)-R_{f}\right]=0
$$


Sehingga dapat dibentuk menjadi

$$
\begin{aligned}
& \frac{d}{d w_{1}}=\varphi\left(w_{1} \sigma_{l 1}^{2}+w_{2} \sigma_{l 1}+\cdots+w_{n} \sigma_{l 1 n}\right)=E\left(R_{1}-C_{1}\right)-R_{f} \\
& \frac{d}{d w_{2}}=\varphi\left(w_{1} \sigma_{l 1}+w_{2} \sigma_{l 2}^{2}+\cdots+w_{n} \sigma_{l 2 n}\right)=E\left(R_{2}-C_{2}\right)-R_{f} \\
& \vdots \\
& \frac{d}{d w_{n}}=\varphi\left(w_{1} \sigma_{l 1 n}+w_{2} \sigma_{l 2 n}+\cdots+w_{n} \sigma_{l 1}^{2}\right)=E\left(R_{n}-C_{n}\right)-R_{f}
\end{aligned}
$$

Kontribusi resiko saham i terhadap total resiko portofolio

$$
\begin{aligned}
& \sigma_{l 1, m}=\left(w_{1} \sigma_{l 1}{ }^{2}+w_{2} \sigma_{l 1}+\cdots+w_{n} \sigma_{l 1 n}\right) \\
& \sigma_{l 2, m}=\left(w_{1} \sigma_{l 1}+w_{2} \sigma_{l 2}{ }^{2}+\cdots+w_{n} \sigma_{l 2 n}\right) \\
& \quad \vdots \\
& \sigma_{l 1, m}=\left(w_{1} \sigma_{l 1 n}+w_{2} \sigma_{l 2 n}+\cdots+w_{n} \sigma_{l 1}{ }^{2}\right)
\end{aligned}
$$

Untuk semua saham dalam portofolio dapat dibentuk menjadi

$$
\varphi \cdot \sigma_{l i, m}=E\left(R_{i}-C_{i}\right)-R_{f}
$$

Untuk portofolio pasar, sehingga menjadi

$$
\begin{gathered}
\varphi \cdot \sigma_{l 1, m}=E\left(R_{m}-C_{m}\right)-R_{f} \\
\varphi=\frac{E\left(R_{m}-C_{m}\right)-R_{f}}{\sigma_{l^{\prime}, m}}
\end{gathered}
$$

Substitusi persamaan (21) ke persamaan (20) sehingga menjadi

$$
\begin{aligned}
\varphi \cdot \sigma_{l i, m} & =E\left(R_{i}-C_{i}\right)-R_{f} \\
\frac{E\left(R_{m}-C_{m}\right)-R_{f}}{\sigma_{l i, m}} \cdot \sigma_{l i, m} & =E\left(R_{i}-C_{i}\right)-R_{f} \\
E\left(R_{i}-C_{i}\right) & =R_{f}+\frac{E\left(R_{m}-C_{m}\right)-R_{f}}{\sigma_{l m, m}} \cdot \sigma_{l i, m} \\
E\left(R_{i}\right)-E\left(C_{i}\right) & =R_{f}+\frac{E\left(R_{m}-C_{m}-R_{f}\right)}{\sigma_{l m, m}} \cdot \sigma_{l i, m} \\
E\left(R_{i}\right) & =R_{f}+E\left(C_{i}\right)+\frac{E\left(R_{m}-C_{m}-R_{f}\right)}{\sigma_{l m, m}} \cdot \sigma_{l i, m} \\
E\left(R_{i}\right) & =R_{f}+E\left(C_{i}\right)+E\left(R_{m}-C_{m}-R_{f}\right) \frac{\sigma_{l i, m}}{\sigma_{l m, m}} \\
E\left(R_{i}\right) & =R_{f}+E\left(C_{i}\right)+\lambda \frac{\sigma_{l i, m}}{\sigma_{l m, m}} \\
E\left(R_{i}\right) & =R_{f}+E\left(C_{i}\right)+\lambda \beta_{l i}
\end{aligned}
$$

dengan $\lambda=E\left(R_{m}-C_{m}-R_{f}\right)$

nilai $\lambda$ menunjukkan konstanta pada beta likuiditas yang diperoleh berdasarkan nilai ekspektasi dari return pasar dikurangi dengan likuiditas pasar dan return bebas resiko. Beta likuiditas $\left(\beta_{l l}\right)$ pada 
metode LCAPM terdapat empat resiko sistematis beta. $\beta_{1 i}$ memiliki hubungan searah (positif) antara return sekuritas dan return pasar, $\beta_{2 i}$ memiliki hubungan searah (positif) antara likuiditas sekuritas dengan likuiditas pasar, $\beta_{3 i}$ memiliki hubungan berlawanan (negatif) antara likuiditas sekuritas dengan likuiditas pasar, dan $\beta_{4 i}$ memiliki hubungan berlawanan (negatif) antara likuiditas sekuritas dengan return pasar.

$$
\begin{array}{ll}
\beta_{1 i}=\frac{\operatorname{Cov}\left(R_{i}, R_{m}\right)}{\operatorname{Var}\left(R_{m}-C_{m}\right)} & \beta_{3 i}=\frac{\operatorname{Cov}\left(R_{i}, C_{m}\right)}{\operatorname{Var}\left(R_{m}-C_{m}\right)} \\
\beta_{2 i}=\frac{\operatorname{Cov}\left(C_{i}, C_{m}\right)}{\operatorname{Var}\left(R_{m}-C_{m}\right)} & \beta_{4 i}=\frac{\operatorname{Cov}\left(C_{i}, R_{m}\right)}{\operatorname{Var}\left(R_{m}-C_{m}\right)}
\end{array}
$$

Sehingga dapat di bentuk persamaaan LCAPM sebagai berikut:

$$
\begin{aligned}
\bar{R}_{i} & =R_{f}+E\left(C_{i}\right)+\left(\beta_{1 i}+\beta_{2 i}-\beta_{3 i}-\beta_{4 i}\right) \lambda \\
& =R_{f}+E\left(C_{i}\right)+\lambda \beta_{1 i}+\lambda \beta_{2 i}-\lambda \beta_{3 i}-\lambda \beta_{3 i}
\end{aligned}
$$

3. Pembentukan Portofolio Optimal LCAPM

Model LCAPM mengkombinasikan sebanyak $p$ aset-aset yang beresiko dan sebuah aset bebas resiko. Selain itu, expected return dipengaruhi oleh likuiditas $\left(C_{p}\right)$, sehingga terbentuk expected return portofolio dari kombinasi sekuritas asset beresiko dan asset bebas resiko pada LCAPM dapat ditulis sebagai berikut:

$$
\bar{R}_{i}=(1-w) R_{f}+w E\left(R_{p}-C_{p}\right)
$$

Persamaan (4-47) (17) dapat dibentuk menjadi

$$
-\frac{\sum_{i=1}^{n} w_{i}\left[E\left(R_{i}-C_{i}\right)-R_{f}\right]}{\left(\sum_{i=1}^{n} w_{i}^{2} \sigma_{l i}^{2}+\sum_{i=1}^{n} \sum_{j=1}^{n} w_{i} w_{j} \sigma_{l i j}\right)} \cdot\left(\sum_{i=1}^{n} w_{i} \sigma_{l i}^{2}+\sum_{i=1}^{n} w_{j} \sigma_{l i j}\right)+\left[E\left(R_{i}-C_{i}\right)-R_{f}\right]=0
$$

Misalkan $\varphi=\frac{\sum_{i=1}^{n} w_{i}\left[E\left(R_{i}-C_{i}\right)-R_{f}\right]}{\left(\sum_{i=1}^{n} w_{i}^{2} \sigma_{l i}^{2}+\sum_{i=1}^{n} \sum_{j=1}^{n} w_{i} w_{j} \sigma_{l i j}\right)}$ sehingga dapat dibentuk menjadi

$$
-\varphi \cdot\left(\sum_{i=1}^{n} w_{i} \sigma_{l i}^{2}+\sum_{i=1}^{n} w_{j} \sigma_{l i j}\right)+\left[E\left(R_{i}-C_{i}\right)-R_{f}\right]=0
$$

Persamaan (4-56) (26) dapat dibentuk menjadi

$$
\varphi \cdot\left(\sum_{i=1}^{n} w_{i} \sigma_{l i}^{2}+\sum_{i=1}^{n} w_{j} \sigma_{l i j}\right)=\left[E\left(R_{i}-C_{i}\right)-R_{f}\right]
$$

Uraian dari persaman (4-57) (27), diperoleh 


$$
\begin{aligned}
& \varphi w_{1} \sigma_{l 1}^{2}+\varphi w_{2} \sigma_{l 1}+\cdots+\varphi w_{n} \sigma_{l 1 n}=E\left(R_{1}-C_{1}\right)-R_{f} \\
& \varphi w_{1} \sigma_{l 1}+\varphi w_{2} \sigma_{l 2}{ }^{2}+\cdots+\varphi w_{n} \sigma_{l 2 n}=E\left(R_{2}-C_{2}\right)-R_{f} \\
& \vdots \\
& \varphi w_{1} \sigma_{l 1 n}+\varphi w_{2} \sigma_{l 2 n}+\cdots+\varphi w_{n} \sigma_{l 1}^{2}=E\left(R_{n}-C_{n}\right)-R_{f}
\end{aligned}
$$

Sehingga dapat di bentuk matriks sebagai berikut

$$
\left(\begin{array}{cccc}
\sigma_{l 1}^{2} & \sigma_{l 12} & \cdots & \sigma_{l 1 n} \\
\sigma_{l 12} & \sigma_{l 2}^{2} & \cdots & \sigma_{l 2 n} \\
\vdots & \vdots & \ddots & \vdots \\
\sigma_{l 1 n} & \sigma_{l 2 n} & \cdots & \sigma_{l n}^{2}
\end{array}\right)\left(\begin{array}{c}
\varphi w_{1} \\
\varphi w_{2} \\
\vdots \\
\varphi w_{n}
\end{array}\right)=\left(\begin{array}{c}
E\left(R_{1}-C_{1}\right)-R_{f} \\
E\left(R_{2}-C_{2}\right)-R_{f} \\
\vdots \\
E\left(R_{n}-C_{n}\right)-R_{f}
\end{array}\right)
$$

Persamaan (4-59) (29) asumsikan $z_{i}=\varphi w_{i}$ dengan $z_{i}$ merupakan investasi optimal pada setiap sekuritas portofolio. Selain itu, terdapat matriks Varian-Kovarian likuiditas $\left(\Sigma_{l}\right)$ sehingga persamaan (4-59) (29) menjadi

$$
\begin{aligned}
\sum_{l} z_{i} & =\left[E\left(R_{1}-C_{1}\right)-R_{f}\right]^{*} \\
z_{i} & =\sum_{l}^{-1}\left[E\left(R_{1}-C_{1}\right)-R_{f}\right]^{*}
\end{aligned}
$$

$z_{i}$ merupakan fungsi objektif (Objective function) yang dimaksimumkan yang harus sama dengan fungsi kendala $\Sigma w_{i}=1$. Jika masing-masing komposisi saham yang dijumlahkan belum sama dengan satu maka belum merupakan proporsi portofolio, sehingga $z_{i}$ harus dibagi dengan $\sum_{i=1}^{n} z_{i}$ yang akan diperoleh proporsi saham $\left(w_{i}\right)$ portofolio model LCAPM adalah sebagai berikut:

$$
\begin{aligned}
w_{i} & =\frac{z_{i}}{\sum_{i=1}^{n} z_{i}} \\
& =\frac{1}{1_{n}{ }^{T} \cdot \sum_{l}{ }^{-1}\left[E\left(R_{i}-C_{i}\right)-R_{f}\right]^{*}} \cdot \sum_{l}{ }^{-1}\left[E\left(R_{i}-C_{i}\right)-R_{f}\right]^{*}
\end{aligned}
$$

\section{Hasil dan Pembahasan}

LCAPM (Liquidity Adjusted Capital asset pricing model) dapat di analisa dengan bantuan software MATLAB dengan rumus model LCAPM sebagai berikut:

$$
\bar{R}_{i}=R_{f}+E\left(C_{i}\right)+\lambda \beta_{1 i}+\lambda \beta_{2 i}-\lambda \beta_{3 i}-\lambda \beta_{4 i}
$$

$E\left(C_{i}\right)$ menunjukkan expected return likuiditas saham yang diperoleh berdasarkan TVA (Trading Volume Activity). Beta sebagai pengukur resiko sistematis pada LCAPM dipengaruhi oleh empat resiko beta antara lain:

a. $\beta_{1 i}$ erupakan hasil bagi antara $C\left(R_{i}, R_{m}\right)$ dan $V\left(R_{M}-C_{M}\right)$ sehingga expected return LCAPM dipengaruhi oleh return sekuritas terhadap return pasar.

b. $\beta_{2 i}$ merupakan hasil bagi antara $C \quad\left(C_{i}, C_{m}\right)$ dan $V \quad\left(R_{M}-C_{M}\right)$ sehingga expected return LCAPM dipengaruhi oleh likuiditas sekuritas terhadap likuiditas pasar.

c. $\beta_{3 i}$ merupakan hasil bagi antara $C \quad\left(R_{i}, C_{m}\right)$ dan $V \quad\left(R_{M}-C_{M}\right)$ sehingga expected return LCAPM dipengaruhi oleh return sekuritas terhadap likuiditas pasar. 
d. $\beta_{4 i}$ merupakan hasil bagi antara $C \quad\left(C_{i}, R_{m}\right)$ dan $V \quad\left(R_{M}-C_{M}\right)$ sehingga expected return LCAPM dipengaruhi oleh likuiditas sekuritas terhadap return pasar.

Analisa mengenai Expected return LCAPM dapat terlihat pada tabel 1 berikut:

Tabel 1 Expected Return LCAPM.

\begin{tabular}{lcccccc}
\hline Saham & $\boldsymbol{E}\left(\boldsymbol{C}_{\boldsymbol{i}}\right)$ & $\boldsymbol{\beta}_{\mathbf{1}}$ & $\boldsymbol{\beta}_{\mathbf{2}}$ & $\boldsymbol{\beta}_{\mathbf{3}}$ & $\boldsymbol{\beta}_{\mathbf{4}}$ & $\begin{array}{c}\text { Expected } \\
\text { Return LCAPM }\end{array}$ \\
\hline AALI & 0,0010 & $-0,8450$ & $0,0678 \mathrm{E}-07$ & $0,2525 \mathrm{E}-05$ & $-0,0014$ & 0,1123 \\
AKRA & 0,0022 & 1,3726 & $0,2501 \mathrm{E}-07$ & $0,4752 \mathrm{E}-05$ & $-0,0039$ & $-0,0113$ \\
BSDE & 0,0018 & 2,4198 & $0,5278 \mathrm{E}-07$ & $0,2166 \mathrm{E}-05$ & $-0,0048$ & $-0,0706$ \\
CPIN & 0,0006 & 2,0028 & $0,1536 \mathrm{E}-07$ & $0,2677 \mathrm{E}-05$ & $-0,0007$ & $-0,0482$ \\
ICBP & 0,0006 & 1,2714 & $0,1498 \mathrm{E}-07$ & $0,2541 \mathrm{E}-05$ & 0,0001 & $-0,0070$ \\
INDF & 0,0013 & $-0,0992$ & $0,2016 \mathrm{E}-07$ & $-0,2109 \mathrm{E}-05$ & 0,0041 & 0,0710 \\
INTP & 0,0011 & 0,9602 & $0,0830 \mathrm{E}-07$ & $0,1165 \mathrm{E}-05$ & $-0,0002$ & 0,0110 \\
JSMR & 0,0012 & 0,7362 & $0,1227 \mathrm{E}-07$ & $0,1185 \mathrm{E}-05$ & 0,0002 & 0,0237 \\
KLBF & 0,0012 & 0,9085 & $0,3139 \mathrm{E}-07$ & $-0,0225 \mathrm{E}-05$ & 0,0016 & 0,0141 \\
LPKR & 0,0027 & 1,9885 & $0,6977 \mathrm{E}-07$ & $0,5548 \mathrm{E}-05$ & $-0,0194$ & $-0,0463$ \\
PGAS & 0,0010 & $-0,1821$ & $0,1134 \mathrm{E}-07$ & $-0,3579 \mathrm{E}-05$ & $-0,0005$ & 0,0751 \\
SMGR & 0,0015 & 1,6259 & $0,0668 \mathrm{E}-07$ & $0,1916 \mathrm{E}-05$ & $-0,0046$ & $-0,0263$ \\
UNVR & 0,0003 & 0,5195 & $0,0265 \mathrm{E}-07$ & $0,0624 \mathrm{E}-05$ & $-0,0001$ & 0,0349 \\
\hline
\end{tabular}

Berdasarkan tabel 1 menunjukkan bahwa terdapat nilai expected return LCAPM yang negatif. Sahamsaham yang mempunyai expected return LCAPM negatif yaitu saham AKRA, BSDE, CPIN, ICBP, LPKR dan SMGR. Portofolio optimal didasarkan pada saham-saham yang mempunyai expected return yang positif, sehingga saham-saham yang mempunyai expected return LCAPM negatif tidak diikutsertakan atau dihilangkan dalam portofolio.

Tabel 2 Expected Return LCAPM Positif.

\begin{tabular}{lcccccc}
\hline Saham & $\boldsymbol{E}\left(\boldsymbol{C}_{\boldsymbol{i}}\right)$ & $\boldsymbol{\beta}_{\mathbf{1}}$ & $\boldsymbol{\beta}_{\mathbf{2}}$ & $\boldsymbol{\beta}_{\mathbf{3}}$ & $\boldsymbol{\beta}_{\mathbf{4}}$ & $\begin{array}{c}\text { Expected } \\
\text { Return LCAPM }\end{array}$ \\
\hline AALI & 0,0010 & $-0,8450$ & $0,0678 \mathrm{E}-07$ & $0,2525 \mathrm{E}-05$ & $-0,0014$ & 0,1123 \\
INDF & 0,0013 & $-0,0992$ & $0,2016 \mathrm{E}-07$ & $-0,2109 \mathrm{E}-05$ & 0,0041 & 0,0710 \\
INTP & 0,0011 & 0,9602 & $0,0830 \mathrm{E}-07$ & $0,1165 \mathrm{E}-05$ & $-0,0002$ & 0,0110 \\
JSMR & 0,0012 & 0,7362 & $0,1227 \mathrm{E}-07$ & $0,1185 \mathrm{E}-05$ & 0,0002 & 0,0237 \\
KLBF & 0,0012 & 0,9085 & $0,3139 \mathrm{E}-07$ & $-0,0225 \mathrm{E}-05$ & 0,0016 & 0,0141 \\
PGAS & 0,0010 & $-0,1821$ & $0,1134 \mathrm{E}-07$ & $-0,3579 \mathrm{E}-05$ & $-0,0005$ & 0,0751 \\
UNVR & 0,0003 & 0,5195 & $0,0265 \mathrm{E}-07$ & $0,0624 \mathrm{E}-05$ & $-0,0001$ & 0,0349 \\
\hline
\end{tabular}

Berdasarkan tabel 2 terlihat nilai expected return LCAPM positif dengan nilai $\beta_{1 i}, \beta_{2 i}, \beta_{3 i}, \beta_{4 i}<1$ sehingga fluktuasi return dan likuiditas sekuritas tidak mengikuti pergerakan pasar.

Nilai $\beta_{1 i}$ tertinggi diperoleh dari saham INTP sebesar 0,9185 dengan expected return sebesar 0,0110 $(1,1 \%)$, sedangkan $\beta_{1 i}$ terendah diperoleh dari saham AALI sebesar $-0,8083$ dengan expected return sebesar $0,1123(11,23 \%)$.

Nilai $\beta_{2 i}$ tertinggi diperoleh dari saham KLBF sebesar 3,0027E-08 dengan expected return sebesar $0,0141(1,41 \%)$, sedangkan $\beta_{2 i}$ terendah diperoleh dari saham UNVR sebesar 2,5387E-09 dengan expected return sebesar 0,0349 (3,49\%).

Nilai $\beta_{3 i}$ tertinggi diperoleh dari saham AALI sebesar 2,415E-06 dengan expected return sebesar $0,1123(11,23 \%)$, sedangkan $\beta_{3 i}$ terendah diperoleh dari saham PGAS sebesar -3,42E-06 dengan expected return sebesar $0,0751(7,51 \%)$.

Nilai $\beta_{4 i}$ tertinggi diperoleh dari saham INDF sebesar 0,003917 dengan expected return sebesar $0,0710(7,10 \%)$, sedangkan $\beta_{4 i}$ terendah diperoleh dari saham UNVR sebesar -8E-05 dengan expected return sebesar $0,0349(3,49 \%)$. 
Tabel 3 Beta Likuiditas dengan Expected Return LCAPM.

\begin{tabular}{lcc}
\hline Saham & $\boldsymbol{\beta}_{\boldsymbol{l i}}=\boldsymbol{\beta}_{\mathbf{1}}+\boldsymbol{\beta}_{\mathbf{2}}-\boldsymbol{\beta}_{\mathbf{3}}-\boldsymbol{\beta}_{\mathbf{4}}$ & Expected Return LCAPM \\
\hline AALI & $-0,8436$ & 0,1123 \\
PGAS & $-0,1816$ & 0,0751 \\
INDF & $-0,1033$ & 0,0710 \\
UNVR & 0,5196 & 0,0349 \\
JSMR & 0,7360 & 0,0237 \\
KLBF & 0,9069 & 0,0141 \\
INTP & 0,9604 & 0,0110 \\
\hline
\end{tabular}

Berdasarkan tabel 3 menunjukkan bahwa expected return LCAPM tertinggi diperoleh dari saham AALI sebesar 0,1123 dengan beta likuiditas terendah sebesar -0,80694, sedangkan expected return LCAPM terendah diperoleh dari saham INTP sebesar 0,91869 dengan beta likuiditas tertinggi sebesar 0,91869 . Dengan demikian, beta likuiditas digunakan sebagai resiko sistematis dari masing-masing saham. Hal ini dikarenakan semakin tinggi nilai expected return LCAPM maka semakin kecil nilai beta likuiditas dan sebaliknya semakin rendah nilai expected return LCAPM maka semakin tinggi nilai beta likuiditas. Grafik hubungan antara expected return dan beta LCAPM dapat dilihat pada gambar 1.

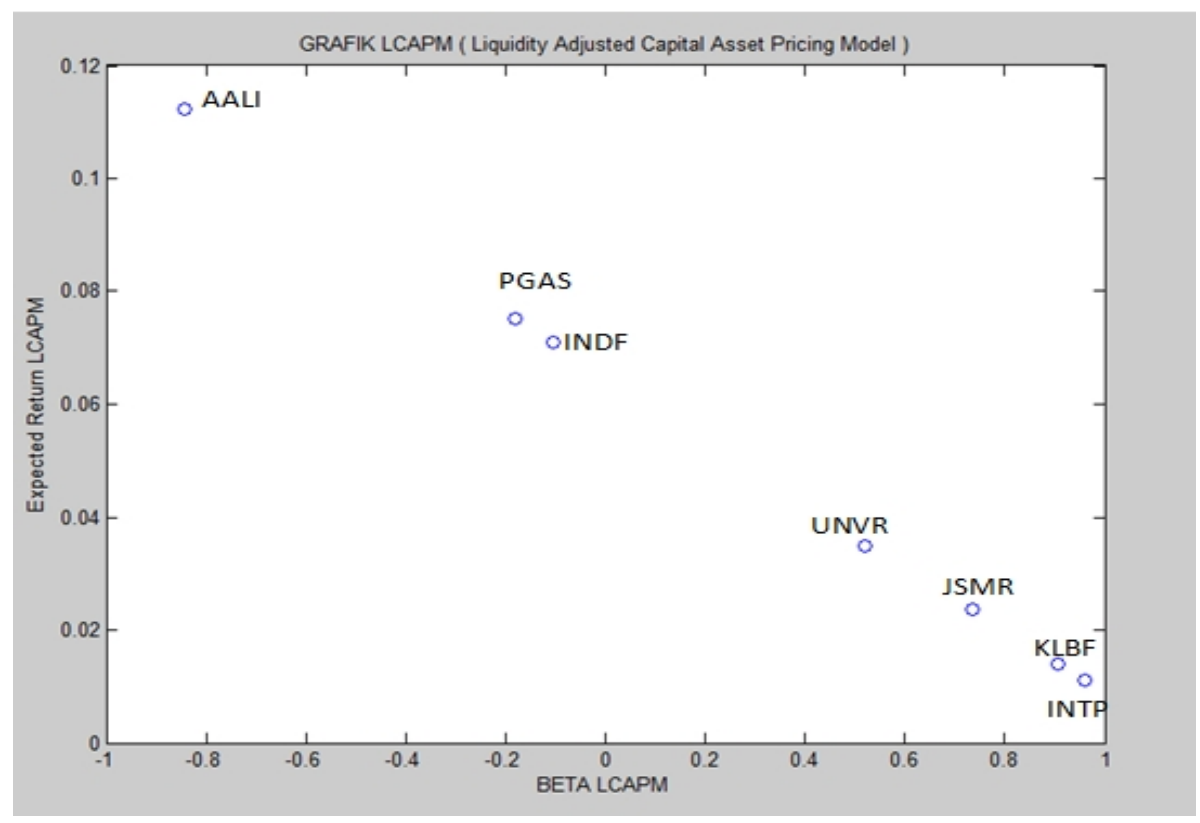

Gambar 1 Grafik Saham LCAPM.

\section{Pembentukan Portofolio Optimal CAPM \& LCAPM}

Portofolio optimal CAPM dan LCAPM dapat dibentuk dengan cara memilih saham-saham yang mempunyai expected return positif, sehingga saham yang mempunyai expected return negatif tidak diikutsertakan atau dihilangkan dalam portofolio. Tabel expected return positif CAPM dan LCAPM adalah sebagai berikut:

Tabel 4 Expected Return CAPM dan LCAPM.

\begin{tabular}{ccccc}
\hline Saham & $\boldsymbol{\beta}_{i}$ & $\begin{array}{c}\text { Expected Return } \\
\text { CAPM }\end{array}$ & $\boldsymbol{\beta}_{l_{l}}=\boldsymbol{\beta}_{1}+\boldsymbol{\beta}_{2}-\boldsymbol{\beta}_{3}-\boldsymbol{\beta}_{4}$ & $\begin{array}{c}\text { Expected Return } \\
\text { LCAPM }\end{array}$ \\
\hline
\end{tabular}




\begin{tabular}{lllll}
\hline AALI & $-0,8450$ & 0,1114 & $-0,8436$ & 0,1123 \\
PGAS & $-0,1821$ & 0,0741 & $-0,1816$ & 0,0751 \\
INDF & $-0,0992$ & 0,0695 & $-0,1033$ & 0,0710 \\
UNVR & 0,5195 & 0,0347 & 0,5196 & 0,0349 \\
JSMR & 0,7362 & 0,0225 & 0,7360 & 0,0237 \\
KLBF & 0,9085 & 0,0128 & 0,9069 & 0,0141 \\
INTP & 0,9602 & 0,0099 & 0,9604 & 0,0110 \\
\hline
\end{tabular}

Pembentukan portofolio optimal ini bertujuan untuk memperoleh nilai expected return dan resiko dalam portofolio. Sebelum pembentukan portofolio optimal, terlebih dahulu harus menentukan pemilihan kelompok saham-saham dalam portofolio. Pemilihan tersebut didasarkan pada kebijakan masing-masing investor yang ingin memilih saham apa saja yang sekiranya dapat memberi nilai return yang maksimal. Berikut ini tabel pemilihan portofolio CAPM dan LCAPM:

Tabel 5 Pemilihan Portofolio CAPM dan LCAPM.

\begin{tabular}{ccc}
\hline Portofolio $A$ & Portofolio B & Portofolio C \\
\hline AALI & AALI & UNVR \\
PGAS & PGAS & JSMR \\
INDF & INDF & KLBF \\
UNVR & & INTP \\
JSMR & & \\
KLBF & & \\
INTP & & \\
\hline
\end{tabular}

Berdasarkan tabel 5 menunjukkan bahwa terdapat 3 (tiga) kelompok portofolio. Portofolio A terdiri dari seluruh saham yang mempunyai expected return positif yaitu saham AALI, PGAS, INDF, UNVR, JSMR, KLBF dan INTP. Portofolio B terdiri dari 3 (tiga) saham yang mempunyai expected return CAPM dan LCAPM tertinggi yaitu saham AALI, PGAS dan INDF. Portofolio C terdiri dari 4 (empat) saham yang mempunyai ecxpected return CAPM dan LCAPM terendah yaitu saham UNVR, JSMR, KLBF dan INTP.

Expected return dan resiko portofolio baik CAPM maupun LCAPM diperoleh melalui proporsi (bobot) masing-masing saham dalam portofolio. Proporsi (bobot) saham di hitung dengan bantuan software MATLAB.

Proporsi saham $\left(w_{i}\right)$ portofolio optimal model CAPM adalah sebagai berikut:

$$
w_{i}=\frac{1}{1_{n}{ }^{T} \cdot \sum^{-1}\left(\bar{R}_{i}-R_{f}\right)^{*}} \cdot \Sigma^{-1}\left(\bar{R}_{i}-R_{f}\right)^{*}
$$

Proporsi saham $\left(w_{i}\right)$ portofolio optimal model LCAPM adalah sebagai berikut:

$$
w_{i}=\frac{1}{1_{n}{ }^{T} \cdot \sum_{l}{ }^{-1}\left[E\left(R_{1}-C_{1}\right)-R_{f}\right]^{*}} \cdot \sum_{l}^{-1}\left[E\left(R_{1}-C_{1}\right)-R_{f}\right]^{*}
$$

Analisa proporsi saham dalam portofolio optimal model CAPM dan LCAPM adalah sebagai berikut: a. Portofolio A

Analisis proporsi (bobot) masing-masing saham dilakukan untuk memperoleh expected return dan resiko portofolio A. Portofolio A terdiri dari seluruh saham-saham yang mempunyai expected return positif sehingga dengan bantuan software MATLAB diperoleh proposi saham portofolio optimal model CAPM dan LCAPM sebagai berikut:

Tabel 6 Proporsi 1 CAPM dan LCAPM Portofolio A. 


\begin{tabular}{lcc}
\hline Saham & $\begin{array}{c}\text { Proporsi 1 CAPM } \\
\text { Portofolio A }\end{array}$ & $\begin{array}{c}\text { Proporsi 1 LCAPM } \\
\text { Portofolio A }\end{array}$ \\
\hline AALI & $-0,4430$ & $-0,4686$ \\
PGAS & $-0,3737$ & $-0,2996$ \\
INDF & $-0,1115$ & -0.2554 \\
UNVR & $-0,4042$ & $-0,4226$ \\
JSMR & 1,0435 & 1,1029 \\
KLBF & 0,9780 & 1,0145 \\
INTP & 0,3109 & 0,3287 \\
\hline
\end{tabular}

Berdasarkan tabel 6 terlihat proporsi CAPM dan LCAPM masing-masing saham pada portofolio A. Proporsi 1 CAPM pada portofolio A terdapat saham yang mempunyai proporsi negatif yaitu saham AALI dengan proporsi $-0,4430$ (-44,3\%), PGAS dengan proporsi $-0,3737$ (-37,37\%), INDF dengan proporsi $-0,1115(-11,15 \%)$ dan UNVR dengan proporsi $-0,4042$ (-40,42\%). Proporsi 1 LCAPM pada portofolio A yang mempunyai proporsi negatif yaitu saham AALI dengan proporsi $0,4686(-46,86 \%)$, PGAS dengan proporsi $-0,2996(-29,96 \%)$, INDF dengan proporsi -0.2554 ($25,54 \%)$ dan UNVR dengan proporsi $-0,4226$ (-42,26\%). Proporsi tersebut masih ada yang mempunyai proporsi negatif, sehingga perlu adanya pembentukan proporsi baru dengan tidak melibatkan saham yang mempunyai proporsi negatif. Proporsi 2 model CAPM dan LCAPM portofolio A adalah sebagai berikut:

Tabel 7 Proporsi 2 CAPM dan LCAPM Portofolio A.

\begin{tabular}{lcc}
\hline Saham & $\begin{array}{c}\text { Proporsi 2 CAPM } \\
\text { Portofolio A }\end{array}$ & $\begin{array}{c}\text { Proporsi 2 LCAPM } \\
\text { Portofolio A }\end{array}$ \\
\hline JSMR & 0,3603 & 0,3604 \\
KLBF & 0,3889 & 0,3884 \\
INTP & 0,2508 & 0,2511 \\
\hline
\end{tabular}

Berdasarkan tabel 7 terlihat bahwa keseluruhan proporsi 2 CAPM dan LCAPM pada portofolio A mempunyai proporsi positif. Proporsi tertinggi terdapat pada saham KLBF dengan proporsi CAPM sebesar 0,3889 (38,89\%) dan proporsi LCAPM sebesar 0,3884 (38,84\%), sedangkan proporsi terendah terdapat pada saham INTP dengan proporsi CAPM sebesar 0,2508 $(25,08 \%)$ dan proporsi LCAPM sebesar 0,2511 (25,11\%). Keseluruhan saham mempunyai proporsi positif, sehingga dapat dibentuk expected return dan resiko CAPM maupun LCAPM pada portofolio A sebagai berikut:

Tabel 8 Expected Return dan Resiko Portofolio A.

\begin{tabular}{cc}
\hline $\begin{array}{c}\text { Expected Return CAPM } \\
\text { Portofolio A }\end{array}$ & $\begin{array}{c}\text { Expected Return LCAPM } \\
\text { Portofolio A }\end{array}$ \\
\hline 0,0156 & 0,0168 \\
Resiko Portofolio CAPM & Resiko Portofolio LCAPM \\
0,0017 & 0,0017 \\
\hline
\end{tabular}

Tabel 8 menunjukkan expected return dan resiko CAPM maupun LCAPM pada portofolio A. Berdasarkan tabel tersebut, nilai expected return CAPM pada portofolio A sebesar 0,0156 (1,56\%) dengan resiko $0,0017(0,17 \%)$, sedangkan nilai expected return LCAPM pada portofolio A sebesar 0,0168 (1,68\%) dengan resiko 0,0017 (0,17\%). Dengan demikian, dapat disimpulkan bahwa dengan resiko yang sama nilai expected return LCAPM pada portofolio A lebih tinggi dibandingkan nilai expected return CAPM pada portofolio yang sama.

b. Portofolio B

Proporsi (bobot) masing-masing saham dilakukan untuk memperoleh expected return dan resiko portofolio B. Portofolio B terdiri dari 3 (tiga) saham yang mempunyai expected return tertinggi 
sehingga dengan bantuan software MATLAB diperoleh proposi saham portofolio optimal model CAPM dan LCAPM sebagai berikut:

Tabel 9 Proporsi 1 CAPM dan LCAPM Portofolio B.

\begin{tabular}{lcc}
\hline Saham & $\begin{array}{c}\text { Proporsi 1 CAPM } \\
\text { Portofolio B }\end{array}$ & $\begin{array}{c}\text { Proporsi 1 LCAPM } \\
\text { Portofolio B }\end{array}$ \\
\hline AALI & 0,6065 & 0,5813 \\
PGAS & 0,6173 & 0,4635 \\
INDF & $-0,2238$ & -0.0447 \\
\hline
\end{tabular}

Berdasarkan table 9 terlihat proporsi CAPM dan LCAPM masing-masing saham pada portofolio B. Proporsi 1 CAPM pada portofolio B terdapat saham yang mempunyai proporsi negatif yaitu saham INDF dengan proporsi -0,2238 (-22,38\%), sedangkan proporsi 1 LCAPM portofolio B yang mempunyai proporsi negatif yaitu saham INDF dengan proporsi $-0,0447(-4,47 \%)$. Proporsi 1 tersebut terdapat proporsi negatif, sehingga perlu adanya pembentukan proporsi baru dengan tidak melibatkan saham yang mempunyai proporsi yang negatif. Proporsi 2 model CAPM dan LCAPM portofolio B adalah sebagai berikut:

Tabel 10 Proporsi 2 CAPM dan LCAPM Portofolio B.

\begin{tabular}{lcc}
\hline Saham & $\begin{array}{c}\text { Proporsi 2 CAPM } \\
\text { Portofolio B }\end{array}$ & $\begin{array}{c}\text { Proporsi 2 LCAPM } \\
\text { Portofolio B }\end{array}$ \\
\hline AALI & 0,5503 & 0,5519 \\
PGAS & 0,4497 & 0,4481 \\
\hline
\end{tabular}

Berdasarkan tabel 10 terlihat bahwa keseluruhan proporsi 2 CAPM dan LCAPM pada portofolio B mempunyai proporsi positif. Proporsi tertinggi terdapat pada saham AALI dengan proporsi CAPM sebesar 0,5503 (55,03 \%) dan proporsi LCAPM sebesar 0,5519 (55,19\%), sedangkan proporsi terendah terdapat pada saham PGAS dengan proporsi CAPM sebesar 0,4497 (44,97\%) dan proporsi LCAPM sebesar 0,4481 (44,81\%). Keseluruhan saham proporsi 2 mempunyai proporsi positif, sehingga dapat dibentuk expected return dan resiko CAPM maupun LCAPM pada portofolio B sebagai berikut:

Tabel 11 Expected Return dan Resiko Portofolio B.

\begin{tabular}{cc}
\hline $\begin{array}{c}\text { Expected Return CAPM } \\
\text { Portofolio B }\end{array}$ & $\begin{array}{c}\text { Expected Return LCAPM } \\
\text { Portofolio B }\end{array}$ \\
\hline 0,0946 & 0,0956 \\
Resiko Portofolio CAPM & Resiko Portofolio LCAPM \\
0,0043 & 0,0043 \\
\hline
\end{tabular}

Tabel 11 menunjukkan expected return dan resiko CAPM maupun LCAPM pada portofolio B. Berdasarkan tabel tersebut nilai expected return CAPM pada portofolio B sebesar 0,0946 (9,46\%) dengan resiko $0,0043(0,43 \%)$, sedangkan nilai expected return LCAPM pada portofolio B sebesar 0,0956 (9,56\%) dengan resiko 0,0043 (0,43\%). Dengan demikian, dapat disimpulkan bahwa dengan resiko yang sama nilai expected return LCAPM pada portofolio B lebih tinggi dibandingkan nilai expected return CAPM pada portofolio yang sama.

c. Portofolio C

Analisis proporsi (bobot) masing-masing saham dilakukan untuk memperoleh expected return dan resiko portofolio $C$. Portofolio $C$ terdiri dari 4 (empat) saham yang mempunyai expected return terendah sehingga dengan bantuan software MATLAB diperoleh proposi saham portofolio optimal model CAPM dan LCAPM sebagai berikut:

Tabel 12 Proporsi 1 CAPM dan LCAPM Portofolio C.

\begin{tabular}{ccc}
\hline \multirow{2}{*}{ Saham } & $\begin{array}{c}\text { Proporsi 1 CAPM } \\
\text { Portofolio C }\end{array}$ & $\begin{array}{c}\text { Proporsi 1 LCAPM } \\
\text { Portofolio C }\end{array}$ \\
\hline
\end{tabular}




\begin{tabular}{lll}
\hline UNVR & 0,2338 & 0,2337 \\
JSMR & 0,2761 & 0,2762 \\
KLBF & 0,2980 & 0,2976 \\
INTP & 0,1921 & 0,1924 \\
\hline
\end{tabular}

Berdasarkan tabel 12 terlihat bahwa keseluruhan proporsi 1 CAPM dan LCAPM pada portofolio C mempunyai proporsi positif. Proporsi tertinggi terdapat pada saham KLBF dengan proporsi CAPM sebesar 0,2980 (29,80\%) dan proporsi LCAPM sebesar 0,2976 (29,76\%), sedangkan proporsi terendah terdapat pada saham INTP dengan proporsi CAPM sebesar 0,1921 $(19,21 \%)$ dan proporsi LCAPM sebesar $0,1924(19,24 \%)$. Keseluruhan saham pada proporsi 1 mempunyai proporsi positif, sehingga dapat dibentuk expected return dan resiko CAPM maupun LCAPM pada portofolio C sebagai berikut:

Tabel 13 Expected Return dan Resiko Portofolio C.

\begin{tabular}{cc}
\hline $\begin{array}{c}\text { Expected Return CAPM } \\
\text { Portofolio C }\end{array}$ & $\begin{array}{c}\text { Expected Return LCAPM } \\
\text { Portofolio C }\end{array}$ \\
\hline 0,0200 & 0,0210 \\
Resiko Portofolio CAPM & Resiko Portofolio LCAPM \\
0,0012 & 0,0012 \\
\hline
\end{tabular}

Tabel 13 menunjukkan expexted return dan resiko CAPM maupun LCAPM pada portofolio C. Berdasarkan tabel tersebut nilai expected return CAPM pada portofolio C sebesar 0,0200 (2\%) dengan resiko $0,0012(0,12 \%)$, sedangkan nilai expected return LCAPM pada portofolio C sebesar $0,0210(2,10 \%)$ dengan resiko $0,0012(0,12 \%)$. Dengan demikian, dapat disimpulkan bahwa dengan resiko yang sama nilai expected return LCAPM pada portofolio C lebih tinggi dibandingkan nilai expected return CAPM pada portofolio yang sama.

\section{Kesimpulan}

Expected return portofolio LCAPM yang dihasilkan pada portofolio optimal portofolio B adalah sebesar $0,0956(9,56 \%)$ dengan resiko portofolio sebesar 0,0043 (0,43\%). Proporsi LCAPM terdiri dari saham AALI sebesar 0,5519 (55,19\%) dan saham PGAS sebesar 0,4481 (44,81\%).

\section{Referensi}

[1] Archarya, Viral V dan Pedersen. 2005. Asset pricing with liquidity risk. USA: Journal of Financial Economics.

[2] Gujarati, D.N. 2007. Dasar-Dasar Ekonometrika. Jakarta: Erlangga.

[3] Jogiyanto. 2000. Teori Portofolio dan Analisis Investasi Edisi 2.Yogyakarta: BPFE.

[4] Jogiyanto, Hartono.2010. Teori Portofolio Dan Analisis Investas Edisi Ketujuh, Yogyakarta: BPFE.

[5] Johson, Richard A. 2007. Applied Multivariate Statistical Analysis $6^{\text {th }}$ ed. USA: Pearson Prentice Hall.

[6] Kalangi, Josep B. 2012. Matematika Ekonomi dan Bisnis. Jakarta: Salemba Empat.

[7] Kim, Sunho dan Kuan-Hui Lee. 2011. Pricing of liquidity risk by alternative liquidity measures. Korea: korea university Business School.

[8] Mahmud, Amir dan Rukmana. 2010. Bank Syariah (Teori Kebijakan dan Studi di Indonesia bagian ke -3). Jakarta: Erlangga.

[9] Mulyana, Deden. 2011. Analisis Likuiditas Saham Serta Pengaruhnya Terhadap Harga Saham Pada Perusahaan Yang Berada Pada Indeks LQ-45 Di bursa Efek Indonesia. JURNAL Magister Manajemen Volume 4 Nomor 1 Maret 2011 halaman 77-96.

[10] Nasrudin, M. Irsan \& Suroya, Indra. 2010. Aspek Hukum Pasar Modal Indonesia. Jakarta: Kencana.

[11] Pompe, Sebastian. 2010. Ikhitisar Ketentuan Pasar Modal. Jakarta: PT. Gramedia.

[12] Qudratullah, M.F. 2009. Pengantar Statistika Matematika. Yogyakarta: UIN Sunan kalijaga.

[13] Qudratullah, M. F., Zuliana, Sri U dan Supandi, Epha D. 2012. Statistika. Yogyakarta: SUKA-Press UIN Sunan Kalijaga

[14] Suhartono \& Fadillah Qudsi.2009. Portofolio Investasi \& Bursa Efek. Yogyakarta: UPP STIM YKPN.

[15] Supranto, J. 2008. Statistik Teori dan Aplikasi Edisi ketujuh. Jakarta: Erlangga. 